\title{
Co-incidence of Echinococcus alveolaris and
Echinococcus granulosus in the Lung: A Rare Case
}

\section{Akciğerde Ekinokokkus alveolaris ve Ekinokokkus granülosus Birlikteliği: Nadir Bir Olgu Sunumu}

Berna Akıncı Özyürek', Yurdanur Erdoğan', Sertaç Büyükyaylacı Özden', Funda Demirağ², Hatice Esra Özaydın², Erkmen Gülhan ${ }^{3}$

\section{Abstract}

A 61 -year old male patient was referred to our hospital for further investigation. Thoracic computed tomography (CT) images showed multiple, some cavitatingspicular nodules in both lungs. Positron emission tomography-CT (PET-CT) was showed high metabolic activity uptakes (SUVmax: 4.68) of nodular densities in the left lung and low metabolic activity uptakes of mediastinal lymphadenopathies. Tru-cut lung biopsy was non-diagnostic. The patient was consulted with a thoracic surgeon for the left-sided video-assisted thoracoscopic surgery (VATS). Wedge biopsy from the left lower and upper lobes was performed. The diagnosis was reported as Echinococcus alveolaris. The infectious disease specialist suggested albendazole treatment. Therapeutic left rethoracotomy and wedge resection plus excision of the cyst membrane were performed. The pathology result was reported as co-existence of $E$. alveolaris and $E$. granulosus. The co-existence of $E$. alveolaris and $E$. granulosus is rarely seen. Herein, we present a rare case with its different radiological appearance.

Key words: Echinococcus alveolaris, Echinococcus granulosus, lung.

\section{Özet}

Altmış bir yaşında erkek hasta, çekilen toraks bilgisayarlı tomografisinde her iki akciğerde spiküler uzanım ve bazıları kaviter özellik gösteren çok sayıda nodülleri olması nedeni ile ileri tetkik amaçlı yönlendirilmişti. Çekilen PET-BT'de sol akciğerde nodüler dansite artımlarına ait artmış metabolik aktivite tutulumları (SUVmax: 4.68), mediastende düşük metabolik aktivite tutulumu olan lenfadenopatiler saptandı. Hastaya transtorasik kesici iğne biyopsisi yapıldı, fakat tanısal olmadı. VATS ile sol alt ve üst lobdan wedge biyopsisi yapıldı. Biyopsi sonucu ekinokokkus alveolaris olarak geldi. Hastaya albendozol tedavisi başlandı. Tedavi amaçlı olarak sol retorakotomi yapıldı. Sol üst ve alt lobdan Wedge rezeksiyon ve kist membran eksizyonu yapıldı. Patoloji sonucu ekinokokkus alveolaris ve granülosus birlikteliği olarak raporlandı. Ekinokokkus alveolaris ve granülosus birlikteliği nadiren görülmektedir. Olgumuzu akciğerde bu birlikteliğin görülmesi ve farklı radyolojik görünümü nedeni ile sunmayı amaçladık.

Anahtar Sözcükler: Ekinokokkus alveolaris, Ekinokokkus granülosus, akciğer.
'Department of Chest Diseases, Atatürk Chest Diseases and Thoracic Surgery Training and Research Hospital, Ankara, Turkey 2Department of Pathology, Atatürk Chest Diseases and Thoracic Surgery Training and Research Hospital, Ankara, Turkey

${ }^{3}$ Department of Thoracic Surgery, Atatürk Chest Diseases and Thoracic Surgery Training and Research Hospital, Ankara, Turkey
'Atatürk Göğüs Hastalıkları ve Göğüs Cerrahisi Eğitim Araştırma Hastanesi, Göğüs Hastalıkları, Ankara

${ }^{2}$ Atatürk Göğüs Hastalıkları ve Göğüs Cerrahisi Eğitim Araştırma Hastanesi, Patoloji, Ankara

${ }^{3}$ Atatürk Göğüs Hastalıkları ve Göğüs Cerrahisi Eğitim Araştırma Hastanesi, Göğüs Cerrahisi, Ankara

Submitted (Başvuru tarihi): 10.04.2016 Accepted (Kabul tarihi): 20.09.2016

Correspondence (iletişim): Berna Akıncı Özyürek, Department of Chest Diseases, Atatürk Chest Diseases and Thoracic Surgery Training and Research Hospital, Ankara, Turkey

e-mail: drberna_1982@yahoo.com 
Echinococcosis is a zoonotic disease which is one of the major causes of morbidity and mortality in many parts of the world. The echinococcus (E), which belongs to the cestode family, has four major types: granulosus, alveolaris (multilocularis), vogali, and oligarthus. Of these, E. vogali and oligarthus rarely cause infections in humans.

E. granulosus is the most widespread type. Humans are usually infected by the parasitic eggs transmitted from infected dogs. Echinococcal cysts are most commonly seen in the liver. Via the systemic circulation, they may spread to every organ and tissue in the human body, including the bones. They may reach the lungs through lymphatic or hematogenous dissemination, inhalation or trans-diaphragmatic channels. Hydatid cysts are usually located in right lung and lower lobes. E. granulosus is visualized in the lungs as solitary or multiple, circular or oval, well-circumscribed mass lesions. In the differential diagnosis, lesions such as lung cancer, solitary metastasis, hematoma, and lung abscess should be considered.

E. alveolaris can be visualized in the lungs as peripherally located multiple, cavitary, small, irregular, nodular opacities showing spicular extensions. In the differential diagnosis, metastatic lung diseases, Wegener granulomatosis, and tuberculosis should be considered.

The co-existence of E. alveolaris and E. granulosus is rarely seen. Herein, we present a rare case with differential radiological appearance.

\section{CASE}

A 61 -year old male patient was referred to our hospital from another center for further investigation of malignan$\mathrm{cy}$, as the image in his thoracic computed tomography (CT) showed multiple nodules which had spicular extensions in both lungs, of which some had cavitary characteristics. The patient did not have any active symptoms except coughing. In his physical examination, no pathology was found. In the laboratory values, no abnormality was detected, except a slight leukocytosis. He had 30 pack-years of smoking history. In the pulmonary function tests, small airway obstruction was detected. Fiberoptic bronchoscopy revealed no extraordinary feature. Repeated sputum smears were negative for acid fast bacilli (three times) and PPD was $15 \mathrm{~mm}$; therefore, tuberculosis was excluded. Collagen tissue markers were studied and P-ANCA and C-ANCA values were negative; therefore, Wegener granulomatosis was excluded. Positron emission tomography-CT (PET-CT) was performed with the preliminary diagnosis of a metastatic malignancy. In PET-CT, high metabolic activity uptakes (SUVmax 4.68) of nodular densities of which some were cavitated with $3 \times 2$ being the largest in the left lung; low metabolic activity uptakes (SUVmax 3.54) of aorto-pulmonary, left lower paratracheal, sub-carinal, left hilar lymph nodes in the mediastinum; high metabolic activity uptakes (SUVmax 4.56) of hypodense nodular lesions $1.5 \mathrm{~cm}$ the largest in the liver were detected (Figure 1). Transthoracic lung needle biopsy (TTNB) was performed. Pathological result was reported as wide necrosis areas within the lung parenchyma which lost its normal histological structure with an increased fibrous connective tissue, lymphocyte and plasma cell infiltration. In the parenchyma, epithelioid histiocytes and giant cells, not forming marked granulomas, were seen. Using Verhoeff's elastic dye, these cells were seen to be located adjacent to the vascular structures. No bacilli were detected in the tissue with Ehrlich-ZiehlNeelsen (EZN) dye. It was suggested that infectious agents causing necrotizing granulomatous infections and collagenous vascular diseases characterized by vasculitis must be clinically eliminated. The patient was consulted with the rheumatologist and vasculitis was not considered as a cause of disease. Six repeated sputum smears were negative for acid fast bacilli, fast gene $X$-pert tuberculosis test was performed; all results were negative. The patient was consulted with the gastroenterologist, due to hepatic involvement in PET-CT scans. Abdominal ultrasonography and magnetic resonance imaging (MRI) was performed. In the posterior of the right lobe of the liver, a 20x13-mm septal, thick-walled, cystic lesion was observed. Cyst hydatid $(\mathrm{CH})$ hemagglutination test result was positive at 1/8192 dilution. The patient who was asymptomatic was suggested to be scheduled for follow-up visits every three months for the liver cyst. The patient was consulted with the thoracic surgeon for diagnostic wedge biopsy; the left video-assisted thoracoscopic surgery (VATS) and wedge biopsy from the left lower and upper lobes were performed. In the histopathological examination of the wedge biopsies, PAS $(+)$ painted cuticle membranes were detected on the necrotic material surrounded by fibrous connective tissue. The diagnosis was reported as E. alveolaris. The patient was consulted with the thoracic surgeon and infectious disease specialist. Albendazole treatment was started. Therapeutic left re-thoracotomy and wedge resection from the left upper and lower lobes in combination with excision of the cyst membrane was performed. The pathology was reported as co-existence of E. alveolaris and E. granulosis due to cystic bodies which formed nodular structures and had clear cuticle materials (Figures 2 and 3). The patient is still on systemic 
treatment, and cyst excision via right thoracotomy and liver cyst excision have been planned.

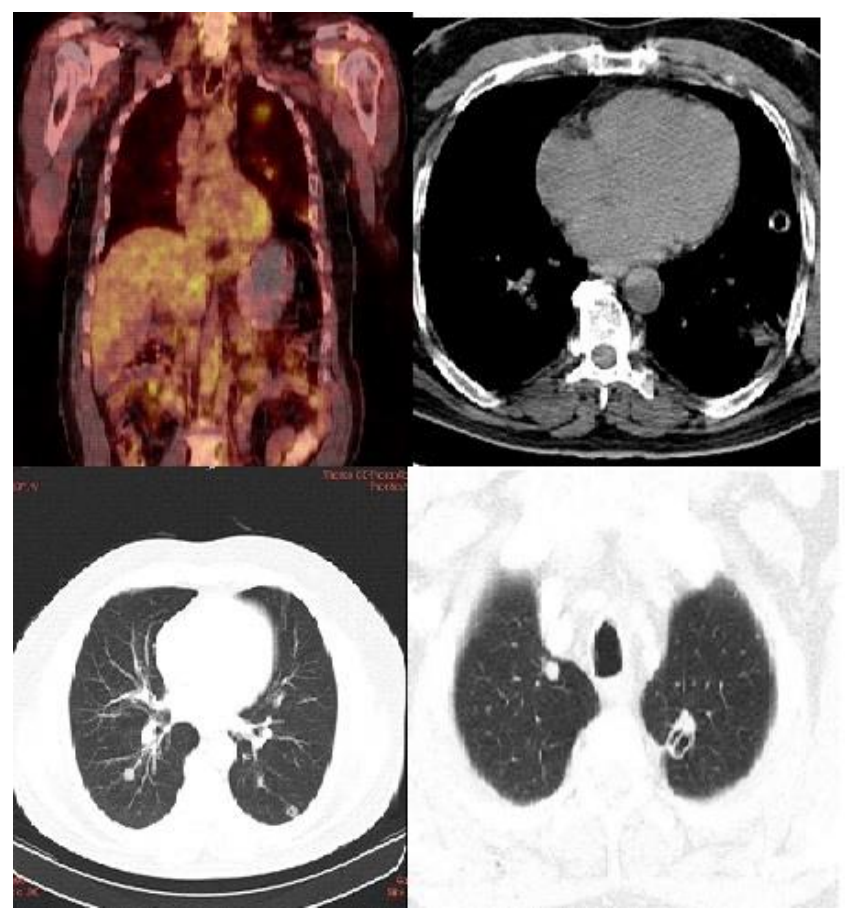

Figure 1: Imaging of PET-CT and thoracic CT: Multiple nodules in both lungs, of which some had cavitary characteristics

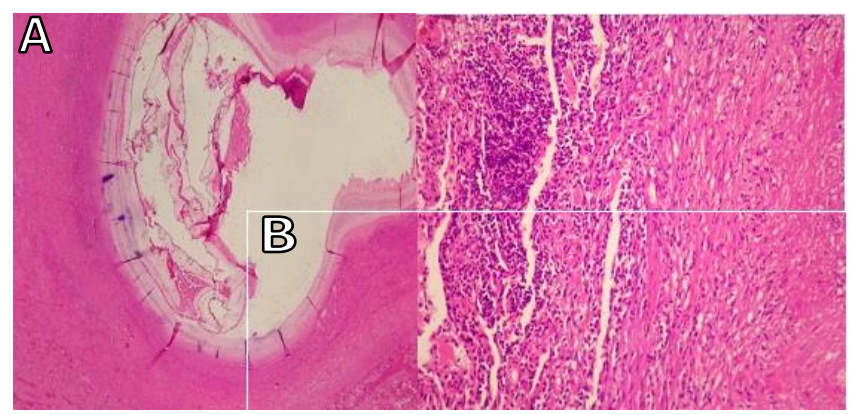

Figure 2A and B: E. alveolaris (HEX40) (A: Cuticle membrane B: Lung parenchyma)
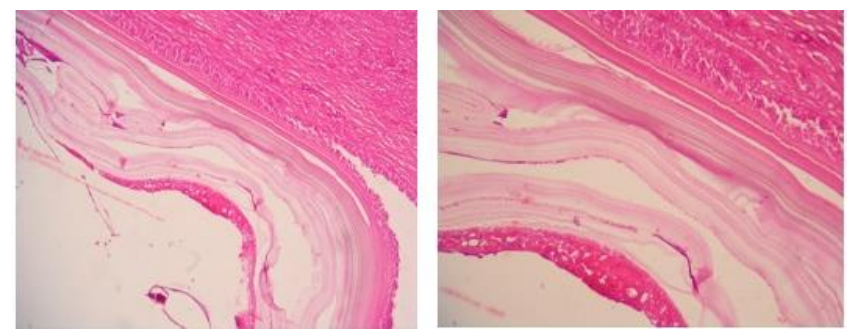

Figure 3: E. granulosis (HEX40) (Cyst membrane)

\section{DISCUSSION}

Turkey is an endemic region for both E. granulosus. It is particularly seen in the Central, East, and South-East Anatolia (1). Hydatid cysts are usually asymptomatic. Symptoms depend on the size and location of the lesion. Cough, chest pain, and hemoptysis are the most frequent symptoms. The most diagnostic symptom in cystic echinococcosis is the expectoration of the cyst fluid or membranes, indicating that the cyst is perforated. The overall status of the patient may deteriorate after perforation. Dyspnea, chest pain, and anaphylaxis can be seen. Lung abscesses may develop, if the cyst is infected. Our case also presented with cough. For diagnostic work-up, it is an important finding to live in an endemic region and history of animal contact. Routine laboratory tests may not be helpful in the diagnosis. Eosinophilia in blood can be detected. Our case owned a dog for one year. No abnormality was detected in routine laboratory tests. Cyst hydatid has a tendency to be located at the right lower lobe of the lung. The percentage of $\mathrm{CH}$ in both liver and lung is 6 to $13 \%$ (2). In the diagnosis of $\mathrm{CH}, \mathrm{X}$-ray imaging of the lung is usually helpful. The presence of a cystic lesion in the liver supports the diagnosis. It is usually seen as solitary or multiple, round or oval well-demarcated mass lesions. In case of alveolar echinococcus, the radiological diagnosis is difficult due to different appearances. E. alveolaris is mostly seen in the liver (3). There can be metastatic lesions in other intra-abdominal organs, bone, muscle, lymph nodes, lungs, brain (4). It is diagnosed by the fine needle aspiration biopsy of the lesions in the lung or liver. In our case, cystic lesions in the liver were also present. In the cranial MRI, there was a hypodense lesion in the left frontal lobe, suggesting a metastasis of E. alveolaris. In the differential diagnosis, metastatic lung cancer Wegener granulomatosis, and tuberculosis were considered, due to the spicular multiple nodules, some which showed cavitation in thoracic CT. Alveolar echinococcus usually shows a gradual progression and, thus, may mimic slow-progressing malignancies. Multiple, irregularly marginated, nodular lesions may be mistaken for malignant metastases. In our case, PET-CT was performed with the preliminary diagnosis of a malignancy. This imaging modality was useful in deciding which nodule TTNB was to be performed from. The TTNB supported vasculitis or granulomatous infections. Blood elements extravasated from the vascular structures in the lung parenchyma adjacent to the nodules, leading to the appearance mimicking vasculitis. Diagnostic wedge resection was, then, performed.

Early diagnosis and treatment are essential in preventing serious disease-related complications and morbidity. Treatment of $\mathrm{CH}$ of the lung is surgical. Following surgery, treatment with systemic benzimidazole derivations is suggested. In patients with non-complicated cysts, small cysts, numerous cysts, and when surgery cannot be performed, 
medical treatment alone is applied. In case of alveolar echinocous, the curative medical treatment is surgery. Early diagnosis is important for the chance of resection, as it is a disease which processes biologically malignant. In Turkey, the disease is usually diagnosed at an advanced stage, and mortality is a result of widespread disease. There are speculative opinions on the utility of chemotherapy; however, it is recommended that the lesion should be re-evaluated for resection in nonresectable lesions after chemotherapy (5-7). In our case, who was asymptomatic, curative surgery was planned, as E. alveolaris was diagnosed after wedge resection. Left re-thoracotomy and upper lobe wedge resection was performed. In the biopsy specimen nodular structures, as well as cystic structures coated with a painted cuticle material, were detected. Pathologically, E. alveolaris and granulosus co-existence was considered. In the literature, there is only one case of co-existent E. granulosus and alveolaris in the liver (8); however, this is the first case of co-existent $E$. alveolaris and E. granulosus in the lung. In patients with cavitating nodular lesions, echinococcal infections must be kept in mind in Turkey where echinococcus is still endemic. Early diagnosis and treatment are essential. Although rare, co-existence of E. alveolaris and E. granulosus infections can be seen.

\section{CONFLICTS OF INTEREST}

None declared.

\section{AUTHOR CONTRIBUTIONS}

Concept - B.A.Ö., Y.E., S.B.Ö., F.D., H.E.Ö., E.G.; Planning and Design - B.A.Ö., Y.E., S.B.Ö., F.D., H.E.Ö., E.G.; Supervision - B.A.Ö., Y.E., S.B.Ö., F.D., H.E.Ö., E.G.; Funding - B.A.Ö., Y.E.; Materials - B.A.Ö., Y.E.; Data Collection and/or Processing - B.A.Ö., Y.E.; Analysis and/or Interpretation - B.A.Ö., Y.E.; Literature Review - B.A.Ö.; Writing - B.A.Ö.; Critical Review - B.A.Ö.

\section{YAZAR KATKILARI}

Fikir - B.A.Ö., Y.E., S.B.Ö., F.D., H.E.Ö., E.G.; Tasarım ve Dizayn - B.A.Ö., Y.E., S.B.Ö., F.D., H.E.Ö., E.G.;
Denetleme - B.A.Ö., Y.E., S.B.Ö., F.D., H.E.Ö., E.G.; Kaynaklar - B.A.Ö., Y.E.; Malzemeler - B.A.Ö., Y.E.; Veri Toplama ve/veya İşleme - B.A.Ö., Y.E.; Analiz ve/veya Yorum - B.A.Ö., Y.E.; Literatür Taraması - B.A.Ö.; Yazıyı Yazan - B.A.Ö.; Eleştirel İnceleme - B.A.Ö.

\section{REFERENCES}

1. Craig PS, McManus DP, Lightowlers MW, Chabalgoity JA, Garcia HH, Gavidia CM, et al. Prevention and control of cystic echinococcosis. Lancet Infect Dis 2007; 7:385-94. [CrossRef]

2. Aytaç A, Yurdakul Y, Ikizler C, Olga R, Saylam A. Pulmonary hidatid disease: report of 100 patients. Ann Thorac Surg 1977; 23:145-51.

3. Gündoğdu C, Arslan R, Arslan MÖ, Gıcık Y. Evaluation of cystic and alveolar echinococcosis cases in people in Erzurum and surrounding cities. Türkiye Parazitoloji Dergisi, 2005; 29:163-6.

4. Özin Y, Kılıç ZM, Parlak E, Kaçar S, Turhan N, Şaşmaz N, Şahin B. Hepatik echinococcus multilocularis: olgu sunum ve literatürün gözden geçirilmesi. Akademik Gastroenteroloji Dergisi 2008; 7:106-10.

5. Wilson JF, Rausch RL. Alveolar hydatid disease: a review of clinical features of 33 indigenous cases of Echinococcus multilocularis infection in Alaskan Eskimos. Am J Trop Med Hyg 1980; 29:1340-55.

6. Amman RW. Improvement of liver resectional therapy by adjuvant chemotherapy in alveolar hydatid disease. Parasitol Res 1991; 77:290-3. [CrossRef]

7. Gillet M, Miguet JP, Mantion G, Bresson-Hadni S, Becker $M C$, Rouget $C$, et al. Orthotopic liver transplantation in alveolar echinococcosis of the liver: analysis of a series of six patients. Transplant Proc 1988; 20(! Suppl 1):5736.

8. Etlik Ö, Ünal Ö, Uygan I, Bay A, Temizöz O, Sakarya ME. Coincidence of Echinococcus alveolaris and granulosis infections in the same liver. Eur J Gen Med 2004; 1:589. 